TAPROBANICA, ISSN 1800-427X. October, 2012. Vol. 04, No. 02: pp. 112-116.

(C) Taprobanica Private Limited, 146, Kendalanda, Homagama, Sri Lanka.

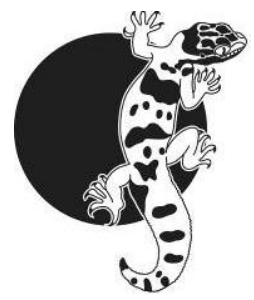

\section{Rhesus macaque and associated problems in Himachal Pradesh - India}

Conflict between humans and primates is common and increasing (Estrada et al., 2012; Nijman, 2010; Sharma et al., 2011). Of the nearly 225 living species of nonhuman primates, three Indian species (i.e., rhesus macaque (Macaca mulatta), bonnet macaque (Macaca radiata) and the hanuman langur (Semnopithecus entellus) have become urbanized. Out of these, rhesus macaques and hanuman langur share food and space with humans in rural and urban areas and are often reported in conflict with humans (Pirta, 2002; Singh, 2000). Conflicts often occur when these primates raid crops of farmers (Forthman, 1986; Hill, 2000; Siex \& Struhsaker, 1999).

Primate conservation in Himachal Pradesh is facing a particular dilemma. Rhesus macaques and hanuman langur often live in temples and towns, where they are worshiped, provisioned and protected by local people (Rajpurohit et al., 2006) as they are considered the image of God Hanuman (Jolly, 1985). However, due to their crop raiding they are disliked in the areas of intensive agriculture, horticulture, and plantations (Roonwal \& Mohnot, 1977). The success of any conservation policy for primates depends upon resolving this conflict (Pirta et al., 1995).

Here we present baseline data on distribution of rhesus macaques and hanuman langur and in forested and non-forested areas of Himachal Pradesh and discuss the intensity of the humannonhuman primate problem both in terms of geographical area and economic loss. Ecological causes which lead to the human-monkey conflict were observed and possible measures are proposed to deal with this conflict.

Himachal Pradesh is mainly a hilly state with elevations ranging from 350 to $6500 \mathrm{~m}$ lying between $30^{\circ} 22^{\prime}$ and $33^{\circ} 12^{\prime} \mathrm{N}$ and from $75^{\circ} 47^{\prime}$ to $79^{\circ} 04^{\prime} \mathrm{E}$ in the lap of the northwest Himalayas. It is divided by a general increase in elevation from west to east and from south to north into four biogeographical regions viz., Shiwalik or Outer Himalayas, Lower or Lesser Himalayas, Higher or Greater Himalayas and Trans Himalayas. The Shiwalik ranges, the southernmost zone, are 40 to $60 \mathrm{~km}$ wide and comprise several highly eroded low ridges. A zone of medium to high ranges, $80 \mathrm{~km}$ wide, the Lesser Himalaya, runs north of the Shiwalik and parallel to the main range. The Great Himalayan ranges lie just towards the North of the Chandrabhaga River in Lahaul-Spiti and Pangi region of Himachal Pradesh. This range is nearly $24 \mathrm{~km}$ wide and rises up to an elevation of over $6000 \mathrm{~m}$. The Spiti area of the state constitutes a separate and distinct unit, the Trans Himalayas. Varied physiographic and climatic factors have given rise to the diverse natural ecosystems found in this region (Mahabal, 2005; Mehta, 2005; Mehta \& Julka, 2002).

Surveys were conducted from October 2004 to September 2006 with the help of local volunteers of Himachal Gyan Vighan Samiti (HGVS), a state social organisation encourages scientific attitudes. Localities were selected on the basis of parameters like access by motor road or tracks, importance due to particular habitat, altitude, status of locality in district and calls from local people complaining about monkey menace. Two workshops (2 and 9 October 2005) were also held to analyse and evaluate observations at Shimla with different groups of volunteers. Direct interviews were conducted with local people in all localities in the local dialect to learn about interaction of rhesus macaque. This helped find groups of monkeys after reaching each locality. In addition, extensive group discussions were conducted. Some assessments of rhesus macaque crop damage were done by categorizing the damage as heavy destruction (above $80 \%$ ), medium (between 40 to $80 \%$ ) or low (below $40 \%$ ). 
We documented that out of 3243 panchayats of the state, 2301 was affected by monkey crop damage. Panchayats are non-partisan councils that settle disputes between individuals and villages across a prescribed area. Of those affected, in 1017 the intensity of damage was less than $40 \%$, in 670 it was between $40-80 \%$, and in $47080 \%$ of crops were destroyed by monkeys. In total, $93.89 \%$ of all panchayats were affected by the monkeys. It was followed by Kangra (90.79\%), Solan (87.2\%) and Sirmour $(80.26 \%)$ Panchayat. The monkey crop raiding was not recorded in any of the panchayats of Lahaul, Spiti, and Kinnaur (Table 1). Conservative estimates put the loss in USD 150,000 to horticulture, USD 200,000 to agriculture and USD $150,000-200,000$ to other sectors. In Bilaspur district all the 38 panchayats had high level of crop damage. It was followed by Sirmour where $58.47 \%$ of the affected panchayats, Chamba (49.23\%) and Shimla (42.23\%) had high levels (> 80\%) of the crop damage. Despite the highest percentage of affected panchayats in Hamirpur, the percentage of highly affected panchayats (crop damage $>80 \%$ of area) was only $6.05 \%$ (Table 1 ). The threat posed by macaques can be placed in perspective when one realizes that $84 \%$ families in the state possess just 1 acre of agricultural land and $70 \%$ people depend on agriculture and horticulture. This forces people to keep their land vacant which is a dangerous in a land-use based economy, like that of Himachal Pradesh.

Table 1: Monkey affected Panchayats in Himachal Pradesh

\begin{tabular}{|c|c|c|c|c|c|}
\hline \multirow[b]{2}{*}{ District } & \multirow[b]{2}{*}{$\begin{array}{l}\text { Total no. of } \\
\text { Panchayats }\end{array}$} & \multirow{2}{*}{$\begin{array}{c}\text { No. of affected } \\
\text { Panchayats } \\
(\%)\end{array}$} & \multicolumn{3}{|c|}{$\begin{array}{l}\text { Level of the damage to crop } \\
\text { (Number of Panchayats) }\end{array}$} \\
\hline & & & $\begin{array}{c}\text { Low } \\
(<40 \%)\end{array}$ & $\begin{array}{l}\text { Medium } \\
(40-80 \%)\end{array}$ & $\begin{array}{c}\text { High } \\
(>80 \%) \\
(\%)\end{array}$ \\
\hline Bilaspur & 151 & $\begin{array}{c}38 \\
(25.17) \\
\end{array}$ & - & - & $\begin{array}{c}38 \\
(100) \\
\end{array}$ \\
\hline Chamba & 283 & $\begin{array}{c}135 \\
(47.7)\end{array}$ & 28 & 40 & $\begin{array}{c}67 \\
(49.23) \\
\end{array}$ \\
\hline Hamirpur & 229 & $\begin{array}{c}215 \\
(93.89) \\
\end{array}$ & 148 & 54 & $\begin{array}{c}13 \\
(6.05) \\
\end{array}$ \\
\hline Kangra & 760 & $\begin{array}{c}690 \\
(90.79) \\
\end{array}$ & 300 & 225 & $\begin{array}{c}165 \\
(23.91) \\
\end{array}$ \\
\hline Kinnaur & 65 & - & - & - & - \\
\hline Kullu & 204 & $\begin{array}{c}139 \\
(68.14) \\
\end{array}$ & 119 & 20 & - \\
\hline Lahul \& Spiti & 41 & - & - & - & - \\
\hline Mandi & 473 & $\begin{array}{c}347 \\
(73.36)\end{array}$ & 114 & 187 & $\begin{array}{c}46 \\
(13.26)\end{array}$ \\
\hline Shimla & 363 & $\begin{array}{c}206 \\
(56.75) \\
\end{array}$ & 19 & 100 & $\begin{array}{c}87 \\
(42.23) \\
\end{array}$ \\
\hline Sirmaur & 228 & $\begin{array}{c}183 \\
(80.26) \\
\end{array}$ & 26 & 50 & $\begin{array}{c}107 \\
(58.47) \\
\end{array}$ \\
\hline Solan & 211 & $\begin{array}{c}184 \\
(87.2)\end{array}$ & 142 & 42 & - \\
\hline Una & 235 & $\begin{array}{c}164 \\
(69.79) \\
\end{array}$ & 40 & 52 & $\begin{array}{c}72 \\
(43.9) \\
\end{array}$ \\
\hline Total & 3243 & $\begin{array}{c}2301 \\
(70.95)\end{array}$ & 936 & 770 & 595 \\
\hline
\end{tabular}

We found that diminishing food in their natural habitat is one of important cause of their crop raiding. During last few decades, availability of a food base in forest areas has decreased due to fragmentation and continuous degradation of broad leaved and evergreen forests, as well as monoculture practices of conifers (Wada, 1983 \& 1984).
Conflicts between humans and monkeys and other wild animals are a manifestation of a larger ecological crisis. Wild animals have moved out of wild habitats to human habitation due to rising human population, increased and constant human interference in the wildlife habitats and continuously declining forest cover. An estimate of Forest Survey of India indicates that during 2000-2003 there was decline of 1453 
$\mathrm{km}^{2}$ in dense forest category and increase in open forest category by $1446 \mathrm{~km}^{2}$ (Table 2). There is heavy demand for horticultural land (Singh, 1991), and the emphasis is on economic crops and other developmental activities (Vaidya \& Sharma, 1994). This may be detrimental to both rhesus macaque and hanuman langur populations. Unlike many other primates, rhesus macaques are well adapted to life near humans and can thrive in highly disturbed environments. $48.5 \%$ of rhesus macaques in northern India live in villages, towns, cities, temples and railway stations. About $37.1 \%$ of the population lives with some human contact on roadsides and canal banks and only $14.4 \%$ of the rhesus macaques in the northern part of the country live in isolation from humans and do not rely on them at all for food (Southwick \& Siddiqi, 1994). Rhesus macaques derive, both directly and indirectly, a substantial part of their diet from human activities (Richard et al., 1989). In fact, up to 93\% of their diet can be from human sources, either from direct handouts or from agricultural sources (Southwick \& Siddiqi, 1994).

Table 2: Change in nature of forest over the period 2000 to 2003 in Himachal Pradesh (SFR, 2003).

\begin{tabular}{c|c|c|c}
\hline \multirow{2}{*}{$\begin{array}{c}\text { Nature of } \\
\text { forest }\end{array}$} & \multicolumn{2}{|c|}{$\begin{array}{c}\text { Area under forest } \\
\text { (sq. } \mathbf{~ k m}) \text { in years }\end{array}$} & \multirow{2}{*}{ Change } \\
\cline { 2 - 3 } & $\mathbf{2 0 0 0}$ & $\mathbf{2 0 0 3}$ & \\
\hline Dense & 10429 & 8976 & - \\
\hline Open & 3931 & 5377 & + \\
\hline Total & $\mathbf{1 4 3 6 0}$ & $\mathbf{1 4 3 5 3}$ & $\mathbf{- 7}$ \\
\hline
\end{tabular}

One of the most important reasons for rise in conflict between humans and nonhuman primates is the rapid growth in population of monkeys due to easily available food resources near human settlements. In 1980, Himachal Pradesh had 60,000 monkey population, but this rose to 317,112 in 2004) and there was a growth of 530\% between 1908 and 2004 (Table 3). This is far greater than the carrying capacity of the state (Mohnot et al., 2005) and if their growth rate is not checked, it will reach alarming proportions in the near future.

One of the important factors for this increase is the sharp decline in the predator population. Potential predators include raptors, dogs, weasels, leopards, tigers, sharks, crocodiles, and snakes (Fooden, 2000). Leopards are numerous in Himachal Pradesh, but they are unable to check the population growth of monkeys due to monkeys association with human settlements.
Table 3: Growth of Rhesus Monkey population in Himachal Pradesh (FD, 2006)

\begin{tabular}{c|c}
\hline $\begin{array}{c}\text { Year of } \\
\text { assessment }\end{array}$ & Population \\
\hline $1964-65$ & $\begin{array}{c}60,000-70,000 \\
\text { (forest rhesus population) }\end{array}$ \\
\hline $1988-89$ & 155,000 \\
\hline 1995 & 223,014 \\
\hline 2004 & 317,112 \\
\hline
\end{tabular}

Entry of monkeys into human habitations for food has lead to their dependence on cooked/processed food. Devotees and animal lovers feel gratified in feeding monkeys in temples, highways or roof tops and consider it a noble deed. As a result, monkeys have become habitual of snatching food from people, attacking them, in extreme cases taking lives. In places, particularly between Solan and Shimla on National Highway 22, they sit along the road and often cause accidents.

Increase in population of monkeys is attributable to other factors also. One of the factors is ban on the export of monkeys for biomedical research. Before 1978, India was the largest exporter of monkeys, exporting 60-70 thousands monkeys per year (Southwick \& Siddiqi, 2001). Due to ban on their export in 1978 and their adaptability to human-disturbed environments, the Indian population of rhesus macaque is increasing (Rao, 2003). Various body parts of monkeys are still used as an effective experimental medium for characterization of various human pathogens (Ahamed et al., 2004; Mehedi et al., 2002; Shafee \& AbuBakar, 2011) and lifting the ban on export of monkeys from India would help control their population.

A thorough understanding of potential risks and perceptions by local people are important factors in any management strategy (Madden, 2004). Restoration of their natural habitat in densely populated areas may decrease conflict. In the long-term, management will be necessary to conserve healthy populations of rhesus macaques and prevent persecution by humans from being a threat to their survival (Muroyama \& Eudey, 2004). Assessment of public opinion is needed for effective management of manmonkey conflict (Marchal \& Hill, 2009; Isabirye et al., 2008; Eudey, 2008).

In a human population of $6,800,000$ in Himachal Pradesh, monkey population is 317,000 (2004 Forest department survey estimates) and must 
have proportionately increased by now. This is one of the largest concentrations of monkeys; in fact there is 1 monkey for every 18 humans. The state forests cannot support such a large concentration of monkeys, therefore they are posing a grave threat to agriculture. Recently, human-wildlife conflict has increased alarmingly and in the absence of an appropriate management plan this problem is only going get worse in future. Today, crop raiding monkeys are the biggest and most urgent issue troubling farmers in Himachal Pradesh.

\section{Acknowledgements}

The authors are grateful to the Chairman, Department of Biosciences, Himachal Pradesh University, Shimla for encouragements. Thanks are also due to Himachal Gyan Vighyan Samiti for field assistance provided in the form of volunteers. Finally Michael Wasserman (McGill University) for reviewing the manuscript.

\section{Literature cited}

Ahamed, T., K. M. Hossain, M. M. Billah, K. M. D. Islam, M. M. Ahasan and M. E. Islam, 2004. Adaptation of Newcastle Disease Virus (NDV) on vero cell line. International Journal of Poultry Science, 3 (2): 153-156.

Estrada, A., B. E. Raboy and L. C. Oliveira, 2012. Agroecosystems and primate conservation in the tropics: a review. American Journal of Primatology, published online: 17 may 2012.

Eudey, A. A., 2008. The crab eating macaque (Macaca fasciclais): widespread and rapidly declining. Primate Conservation, 23: 129-132.

FD (Forest Department), 2006. Himachal Pradesh, Shimla: 50-51.

Fooden, J., 2000. Systematic review of the rhesus macaque, Macaca mulatta (Zimmermann, 1780). Field Zoology, 96: 1-180.

Forthman, Q. D. I., 1986. Activity budgets and consumption of human food in two troops of baboons, Papio anubis, at Gilgil, Kenya. In: Else, J. G. and P. C. Lee (eds.). Primate Ecology and Conservation. Cambridge University: 221-228.

Giriraj, A., S. Babar and C. S. Reddy, 2008. Monitoring of Forest Cover Change in Pranahita Wildlife Sanctuary, Andhra Pradesh, India Using Remote Sensing and GIS. Journal of Environmental Science and Technology, 1: 73-79.
Hill, C. M., 2000. Conflict of interest between people and baboons: Crop raiding in Uganda. International Journal of Primatology, 2: 299-315.

Isabirye-Basuta, G. M. and J. S. Lwanga, 2008. Primate population and their interactions with changing habitats. International Journal of Primatology, 29:35-48.

Jolly, A., 1985. The evolution of primate behavior, (2nd edition), Macmillan, New York: 416.

Lin, Z-S. and H-Y. Liu, 2006. Biodiversity Response to Human-Caused Habitat Destruction in Different Eras.Trends in Applied Sciences Research, 1: 162-171.

Lindburg D. G., 1971. The rhesus monkey in north India: an ecological and behavioral study. In: Rosenblum L.A. (ed.). Primate behavior: developments in field and laboratory research. Academic Press, New York: 106.

Maan, M. A. and A. A. Chaudhry, 2001. Wildlife Diversity in the Punjab (Pakistan). Journal of Biological Sciences, 1: 417-420.

Madden, F., 2004. Creating coexistence between humans and wildlife. Global perspective on local efforts to address human wildlife conflict. Hum Dim Wildlife. 9: 247-257.

Mahabal, A., 2005. Aves. In: Fauna of Western Himalaya. Zoological Survey of India: 275-339.

Makwana S. C., 1978. Field ecology and behavior of the rhesus macaque (Macaca mulatta): Group composition, home range, roosting sites, and foraging routes in the Asarori Forest. Primates, 19 (3): 483-92.

Mani, A., 1981. The Himalayan aspects of change. India International Centre, New Delhi: 481.

Marchal, V. and C. Hill, 2009. Primate cropraiding; A study of local perceptions in four villages in north Sumatra. Indonesia. Primate conservation, 24: 431-435.

Mehedi, M., K. M. Hossain, M. J. F. A. Taimur, B. K. Sil and M. R. Islam, 2002. Haemagglutination antigen preparation of Newcastle Disease Virus on vero cell line. Online Journal of Biological Sciences, 2 (10): 648-649.

Mehta, H. S., 2005. Fauna of Western Himalaya (Part-2): Himachal Pradesh. Zoological survey of India: $1-4$ 
Mehta, H. S. and J. M. Julka, 2002. Mountains: Northwest Himalaya. In: Alfred, J. R. B., A. K. Das and A. K. Sanyal (eds.). Ecosystems of India. Zoological Survey of India: 410.

Mohnot, S. M. and A. K. Chhangani, 2005. Monkey Menace in Himachal Pradesh, Report prepared by the Committee appointed by the AWBI-Ministry of Environment \& Forests, Primate Research Centre: 1-4.

Muroyama, Y. and A. A. Eudey, 2004. Do macaque species have a future? In: Thierry B., M. Singh and W. Kaumanns (eds.). Macaque societies: a model for the study of social organization. Cambridge University: 328-332.

Narwade, S. S., G. A. Jathar and A. R. Rahmani, 2006. Himachal Pradesh. In: Bibliography of the birds of North India. Buceros, 11 (1): 34-54.

Nijman, V. and K. A. -I. Nekaris, 2010. Testing a model for predicting primate crop-raiding using crop- and farm-specific risk values. Applied Animal Behaviour Science, 127: 125-129.

Pirta, R. S., M. Gadgil and A. V. Khaashikar, 1995. Management of the rhesus monkey Macaca mulatta and Langur Presbytis entellus in Himachal Pradesh, India. Biological Conservation, 79: 97106.

Rajpurohit, L. S, A. K. Chhangani, R. S. Rajpurohit, N. R. Bhaker, D. S. Rajpurohit and G. Sharma, 2006. Man monkey conflict and urbanization in non human primates. International Journal of Primatology, 27 (1): 1-17.

Rao, A. J., 2003. Use of nonhuman primates in biomedical research in India: current status and future prospects. In: Vaupel S. (ed.). International perspectives: the future of nonhuman primate resources. Washington DC: 21-28.

Richard, A. F., S. J. Goldstein and R. E. Dewar, 1989. Weed macaques: the evolutionary implications of macaque feeding ecology. International Journal of Primatology, 10 (6): 569594.

Roonwal, M. L. and S. M. Mohnot, 1977. Primates of South Asia. Harvard University Press, Cambridge, Mass, 18: 421.

SFR (State of Forest Reports), 2003. Himachal Pradesh, Forest Survey of India, Dehradun: 63.
Shafee, N. and S. AbuBakar, 2011. Characterization of dengue type 2 NGC virus infection in C6/36, vero and MRC-5 cells. International Journal of Virology, 7 (1): 24-32.

Sharma, G., C. Ram, Devilal and L. S. Rajpurohit, 2011. Study of man-monkey conflict and its management in Jodhpur, Rajasthan, India. Journal of Evolutionary Biology Research, 3 (1):1-3.

Siex, K. S. and T. T. Struhsaker, 1999. Colobus monkey and coconut. A study of perceived humanwildlife conflict. Journal of Applied Ecology, 36: 1009-1020.

Singh, V., 1991. Ecological impact of apple cultivation in the Himalaya. International Book Distributors, Dehradun: 1251.

Southwick, C. H. and M. F. Siddiqi, 1994. Primate commensalisms: the rhesus monkey in India. Review Ecology, 49: 223-31.

Southwick, C. H. and M. F. Siddiqi, 2001. Status, conservation and management of primates in India. In: Gupta A. K. (ed.). Non-human primates of India. Wildlife Institute of India, Dehradun: 81-91.

Vaidya, C. S. and T. R. Sharma, 1994. Decentralised planning model for developing hill areas (a case study of District Shimla, HP). Kurukshetra, 42 (6): 5-10.

Vedwan, N. and R. E. Rhodes, 2001. Climate change in the Western Himalayas of India: a study of local perception and response. Climate Research, 19: 109-117.

Wada, K., 1983. Ecological adaption in rhesus monkey at Kumaon Himalaya. Journal of Bombay Natural History Society, 80: 469-498.

Wada, K., 1984. Rhesus monkey distribution in lower Himalayas and secondary forest succession. Journal of Bombay Natural History Society, 81: 355-362.

Submitted: 29 May 2012, Accepted: 10 August 2012 Sectional Editors: Colin Chapman \& Lee Harding

Vikram Singh $^{\mathbf{1 , 2}}$ and M.L. Thakur ${ }^{1}$

${ }^{1}$ Department of Biosciences, Himachal Pradesh University, Shimla 171 005, India

${ }^{2}$ Email: proliterate@yahoo.com 